\title{
Rape and HIV as Methods of Waging War: Epidemiological Criminology’s Response
}

\author{
Ishita Chowdhury, Mark M. Lanier \\ University of Alabama, Tuscaloosa, USA \\ Email: itchowdhury@crimson.ua.edu
}

Received December $10^{\text {th }}, 2011$; revised January $8^{\text {th }}, 2012$; accepted January $26^{\text {th }}, 2012$

\begin{abstract}
Rape is normally committed, examined and conceptualized as an act committed by an individual and is explained as an act of power and control over the victims. Rape is less often examined from the context of group behavior and as a function of group dynamics. In wartime, rape has historically been associated with "spoils of war" and rape has only recently been used a tactical weapon of war. One tactical objective of rape is to demoralize populations and a more sinister objective is to promote slow genocide when systematic rape is coupled with high rates of HIV infection such as is found in much of continental Africa. We provide an integrative theoretical response, Epidemiological Criminology, and specific policy suggestions to combat this crime.
\end{abstract}

Keywords: HIV; AIDS; Rape; War; Epidemiological Criminology; Genocide

\section{Introduction}

Dating from the very first wars and civil disturbances, "rape and pillage" of the losing force has been one of the "spoils of war" taken by the victors. In ancient times in addition to rape and pillage, slavery was commonly employed against losing families, tribes, city-states or countries. More recently Russian infantrymen raped hundreds of thousands of German women at the conclusion of World War II, particularly in Berlin. Most recently, in contemporary Africa, soldiers are using rape for specific tactical reasons that transcend traditional violations used by conquering armies.

Both in the context of war and outside of war, rape is a crime that often goes unreported by the victim (Kilpatrick, 2000). In the United States it is estimated that over $60 \%$ of rapes/sexual assaults are not reported to the police (RAINN reports). When rape is reported numbers are often disturbingly high. For instance, in the Republic of South Africa (RSA) there are over 50,000 reported rapes every year and nearly three quarters of the offenders are known to the victim (Quantitative Research Findings, 2005). The remaining quarter of reported rapes, or roughly 13,000 rapes, are committed by strangers in RSA. Included among these stranger rapes is the "serial rapist" (deWet, Labuschagne and Chiroro, 2009). The serial rapist has recently been the topic of profiling and the "typical" serial rapist was found to be a laborer, of lower education (Grade 1 - Grade 6) and under 32 years of age. This is the same demographic profile of soldiers in Africa and elsewhere. Soldiers have been identified as rapists on several different instances on the African continent, and elsewhere. One consequence of rape is infection with sexually transmitted diseases, such as HIV.

HIV/AIDS differentially and disproportionally impacts women (Zaitzow, 2001). When coupled with both the physical and psychological trauma associated with rape and war, the added toll of HIV/AIDS infection is significant. It is not hyperbole to state that this could be the "perfect storm" of harm to women. Unfortunately it is all too real and exists. Human trafficking
(Lutya \& Lanier, 2009) is the only other crime that is similarly widespread harmful on multiple fronts.

Despite the chronological and empirical documentation of the act there has never been a theoretical explanation, much less suggestive strategies to combat this ailment founded on applied sociological theory (Merton, 1968) and based on social science empirical analysis. Epidemiological Criminology presents one such bridging theory. This paper explores that theoretical potential in the context of preventing rape as a tactical weapon of war.

\section{Literature Review}

\section{Rape and War: HIV Used as a Weapon of War}

Rape has been used previously as a weapon of war in several African countries, most notably in Rwanda during the 1994 genocide according to Chelala (2005). In war torn Rwanda, rape as a weapon of war has decreased in frequency and it is also reported to have subsided in Sierra Leone and Liberia. However, systematic rape continues on a wide scale in the Democratic Republic of the Congo, Uganda and Sudan (Chelala, 2005). Rape as a war tactic is particularly harmful because women are subjected to humiliation, physically harmed and mentally traumatized. In addition, often as a result, women are also being infected with the deathly diseases such as HIV/AIDS by military personnel and informal militias in war zones (Chelala, 2005).

In Rwanda, HIV infected Hutu militia men were instructed to rape all women in the society with the objective of killing the Tutsi population slowly over time (Sharlach, 2000). International law has responded to the issue of rape in war; however, state governments have responded less enthusiastically in cases of violence against women in times of war. HIV is being utilized by armed forces in Africa as a psychological and biological weapon of war through the "deliberate targeting of civilians through the widespread and systematic use of rape" (Elbe, 
2002). Even though the intent of the HIV infected soldiers committing acts of rape may be difficult to determine, the reality remains that HIV's existence itself makes this practice all the more problematic on human rights, social and medicinal grounds (Lanier, 2006). The use of rape as a war tactic has increased and as a result the probability of contracting HIV through rape has increased (Elbe, 2002). The spread of HIV through rape coupled with the violent nature of the act against non-warring people (women) creates a salient issue in dire need of a resolution, especially in Africa (Elbe, 2002).

\section{The Use of HIV and Rape as a War Tactic in Rwanda}

During the Rwandan genocide in 1994, women were subjected to rape, mainly by the Hutu militia groups known as Interahamwe, by soldiers of the Rwandan armed forces (FAR) and by other civilians (CLG). The Hutu government continued to support these acts of sexual violence with the end goal of eliminating the entire Tutsi race from the Rwandan population (African Union Report, 2008). The “Africa News” interviewed anonymous witness "QBQ"; a woman, who informed the International Criminal Tribunal that the former minister of Family and Women Affairs, Pauline Nyiramasuhuko had ordered the Hutu militia, specifically those men infected with HIV, to "rape all Tutsi women and kill the rest” (Lexis Nexis, 2004). A UNICEF leader stated that Hutu men contaminated with the HIV virus took part in mass rapes of women and girls with the objective being "to inflict slow and lingering, but certain death of the Tutsi population” (Lexis Nexis, 1995). This war tactic took a significant toll on the adult and child population of Rwanda. In 2000 the UNAIDS estimated that 270,000 children in Rwanda had lost their mother or both parents to HIV/AIDS (HRW, 2003). As a result these children were orphaned and given very little assistance and bleak prospects of a future. In addition traditional societal networks had been severely deteriorated by poverty as a result of the HIV/AIDS epidemic and the consequences of the genocide and war which left these children in an even more detrimental position (Rakita, 2004). The children were excluded for being "contaminated by HIV even though they had contracted the disease from birth" (HRW, 2003).

\section{UN Action against Rape in War: Rwanda}

Criminal acts such as the ones mentioned above continued to take place in Rwanda simultaneously with very little punitive action taken, and this lack of punishment eventually led to national reproach of the issue. In an effort to eliminate impunity of genocidally motivated criminal soldiers the United Nations (UN) Security Council established the International Tribunal in Rwanda (UN Resolution 955). This special court was given the power to prosecute any individuals who commit acts of genocide (UN Resolution 955). The Resolution contains a section on crimes against humanity, allowing the court to "prosecute persons responsible for crimes committed as a part of a widespread or systematic attack against any civilian population on national, political, ethnic, racial or religious grounds" (Annex, Article 2: Genocide). Rape is included within that definition.

On September 2, 1998, based on the facts of the Jean Paul Akayesu case, the Trial Chamber declared that rape, would be defined as a "physical invasion of sexual nature committed on a person under circumstances which are coercive and sexual vio- lence are both acts of genocide, so long as they are used with an intent to destroy, in whole or in part, a specific targeted group” (Lexis Nexis, 1998). The prosecution of Jean Paul Akayesu also advocated stronger enforcement of the Convention on the Prevention and Punishment of the Crime of Genocide in Rwanda. The Convention that was initially adopted by the UN on December 9, 1948 during the period of the Holocaust, was later applied to the cases of genocide in Rwanda. Article 2 in the Convention on the Prevention, contains five punishable acts of genocide that stretch further than the "killing" of a groups and encompassed other acts. The list of punishable acts also includes "bodily harm and prevention of birth of a certain group" (CPPCG, Article 2). This inclusion presents a new angle on the use of rape as a war tactic. Since rape cannot be classified as an act that causes "bodily harm and sometimes prevention of birth," the convention allows the punishment of individuals guilty of committing such acts (CPPCG, Article 2).

\section{HIV and Rape Used as a War Tactic in Uganda}

Similar to the case of Rwanda, many Ugandan women are at risk or becoming infected with HIV, and will eventually lose their lives to AIDS because of failure to protect these women from sexual violence (HRW, 2004). In Uganda, soldiers from the Lord's Resistance Army (LRA) use rape and mutilation of women in their attempts to replace a secular government in the country (Chelala, 2004). The LRA also commit the crimes of child abduction, forced "marriage" (female) and institutionalized rape (Harris, 2007). Men are "given” women and girls as a form of property to reward them for "good behavior," “(e.g. following orders to kill prisoners of war and captured villagers)" (Rave Project, 2003). The men are granted complete sexual control over their "wives" and "domestic helpers," and they force their women to submit to rape and other forms of violence (Poe, 2009). The increased level of AIDS infection rates among policeman, prison staff and soldiers are caused by an increase in interaction between members of the armed forces and civilians and high levels of commercial sex (DPA, 2008).

Uganda's concentration camps are substantially responsible for fostering the rapid spread of HIV from military members to the civilian population. According to The World Health Organization (WHO) almost 1.4 million people in northern Uganda have been forced out of their homes, and were placed in over-congested camps with poor sanitation and hygiene conditions (FPA, 2005). Women and children are subjected to the military taking advantage of them sexually and spreading the HIV virus through unprotected sexual contact (Wallis, 2008). Wallis (2008) also stated that HIV/AIDS rates in northern Uganda are "nearly twice as high as the rest of the country because of an 18-year war with the oppressive Lord's Resistance Army rebel group”.

The conditions that exist in Uganda are starkly similar to those that existed in Rwanda. The reason that the Ugandan government continues to commit such cruel acts without being subjected to punishment, is because of the absence of a higher court such as the International Tribune in Rwanda. If actions to reduce catalysts such as these are not taken, then the situation will inevitably worsen over time. Instances of HIV infection will result in even higher mortality rates.

\section{Theoretically Based Policy Initiatives}

It is evident that the use of rape by (often HIV infected) sol- 
diers and militia members, creates considerable physical and emotional harm. We do not suggest that HIV rates are higher in these countries because soldiers infected with HIV are using rape. There are multiple causes of the high rates of HIV infection found in this part of the world. The issue of rape as a weapon of war is linked to the field of Criminology/Criminal Justice, and understood as a type of crime. Meanwhile, the majority of HIV/AIDS prevention education focuses on the medical realm of practicing safe sex through proper contraception use, or abstinence (Lanier, 2010). Targeting these issues separately, and searching for solutions within separate realms, could indeed potentially reduce both issues; however, there may also be benefits that arise from linking these two issues together, merging the two disciplines, and attempting to understand them as a unit.

For instance, Country A may have high levels of HIV present within its population, and as an attempt to reduce the prevalence of HIV the government might target Safe-Sex education stemming completely from the medical/health realm. This policy solution; however, may fail to alleviate the "root" problem effectively; if other underlying issues are present. Perhaps the government is pressuring HIV infected military men of that society, or other HIV infected males to rape the women of that population with an end goal of eradicating the entire population through HIV such as the case in Rwanda. If this is the case, then HIV/AIDS and the "crime" of rape as a weapon of war have merged together to create a whole new disastrous situation, that must be combated; however, not in the same way that they would otherwise be combated individually. Epidemiological Criminology, or EpiCrim, is a development that attempts to combine the Social Science disciplines of Criminology and Health Sciences. Lanier stated that "if crime is presumed to be an indicator of the health of the societal whole (disease), then both Criminal Justice and Criminology, as academic disciplines most likely to address crime issue and Public Health as the academic discipline most likely to examine health issues” (2010: p. 80). EpiCrim claims that the subjects of Criminal Justice and Public Health have been "more divergent than inclusive," and therefore attempts to combine the two disciplines and studies anything that affects the health of a society; be it crime, flu, epidemics, global warming, human trafficking, substance abuse, terrorism or HIV/AIDS (Lanier, 2010: p. 72 \& 93). EpiCrim is essentially the "study of crime as a disease," and consists of "any harmful, depraved, or morbid condition of the mind or society” (Webster's, 2009). EpiCrim addresses the issue of two disciplines studying the same issue through different lenses, and therefore fail to target the "root cause" of the crime (Akers \& Lanier, 2009: p. 4). EpiCrim essentially combines the terminology in the different disciplines in order to gain more cohesive understanding and reach a more effective solutions (Lanier, 2010).

\section{Problem Statement}

The act of rape, from a criminological standpoint has been well documented and studied. For instance, profiles exist for serial rapists and we know that most rapes occur among younger people who know each other (Lanier \& Henry, 2010). Rape is normally committed, examined and conceptualized as an act committed by an individual and is explained as an act of power and control over the victims. Rape is less often examined from the context of group behavior and as a function of group dynamics. Is the underlying pathology that leads to rape the same when committed on a large scale? Treatment and punishment of lone, individual rapists has also been empirically examined from a psychological perspective yet when rape occurs on a larger scale, by groups, sociological explanations are mandated. In this paper we provide the first social psychological explanation and suggest policy and treatment modalities founded on a theoretical model we term Epidemiological Criminology. What has been missing from the research literature is the understanding and profile of rape committed as a tactical weapon in war to spread harmful disease, instead of just as a "spoils of war" (thought the effects on victims are identical). While it is beyond the scope of this paper to provide that analysis we can suggest a theoretical premise that might guide both research and policy efforts as we outline below. One difficulty with researching rape during a time of crisis, such as war, is that the crime transcends both disciplinary boundaries, physical and emotional ones. Few theories are capable of addressing both health and criminological concerns. However, one suggests a bridging capability and thus suggests some practical applications. Epidemiological Criminology may help provide that theoretical guide (Lanier, 2009).

\section{Epidemiological Criminology}

Epidemiological Criminology (EpiCrim) represents an evolving multidisciplinary perspective, which seeks to bring together scholars from criminology, sociology, political science and the health professions for the purpose of formulating an integrative understanding of crime and criminality (among other social ills) as they relate to, and often create, health disparities. As the name implies, Epidemiological Criminology employs a variety of medical model metaphors by which to formulate its theoretical perspective. However, according to David Polizzi (personal cor-respondence) such a formulation is potentially threatened by the use of literal medical model conceptualizations that help to restrict the theoretical possibilities of this approach. For example, by formulating crime as a disease (such as rape) of the social body, it fails to recognize that crime or criminal behavior is symptomatic of an internal dysfunction and not proof of an external contagion (Polizzi \& Lanier, in press).

In 2009 Akers and Lanier first presented an argument for criminal justice, sociology and criminology having roots in public health and epidemiology. Epidemiological Criminology, or "EpiCrim", was presented as a means of "coming full circle" and reuniting these disciplines and provides the theoretical basis for this study. Durkheim first used crime as a barometer of the health of a society so this nothing novel (Durkheim, 1987-1951) though it has been neglected. The following section gives a synopsis of their argument. There is an increasing overlap and blurring of distinctions between public health and criminology (Lanier, Lucken, \& Akers, 2009). Both social science and public health academics and professionals work with marginalized populations; people at high risk to multiple dangers including drug use, health problems, exploitation, and incarceration. AIDS/HIV, for example, provides the first illustration of the interconnection between the two fields since AIDS/HIV was the health threat which first dramatically confronted social service agencies (Lanier, 2006) especially prisons and jails (Braithwaite, Hammett, \& Mayberry, 1996). Victims of systemic rape during war, likewise, fit well under each category and so thus comprise a population of special interest to a public health and social science analytical framework. Al- 
though numerous illustrations can be used to illustrate this merging, there is a scarcity of explicit theoretical and methodological linkage. To address this deficiency, EpiCrim, as a new framework, links methods, and statistical models of public health, which are complemented by their criminological and sociological counterparts (Akers \& Lanier, 2009).

According to Polizzi and Lanier, any attempt to formulate the existence of crime as a type of "social" disease must first clarify the way in which this "disease model" is applicable as a legitimate point of reference by which to study the phenomenon of crime. Epidemiological Criminology, in its attempt to meld epidemiological and criminological theory into an explanatory framework by which to understand the presence of crime as a public health concern, must also be able to conceptualize the relationship between the individual act of crime (or in this case the group act of systematic rape) and the social context from which this activity occurs. The phenomenon of crime, including tactical rape, can be viewed in the same way.

Taken from this perspective crime becomes the symptomatic presence of disease that manifests itself at different localities within the social body (Polizzi, 2010a, 2010b). The symptom of crime therefore, is conceptualized as that which announces the presence of disease within the social body, but is not seen as the cause of the condition that is currently responsible for its illness. Crime, like any other symptom, signals the existence of an underlying condition or emerging pathology that no longer continues to progress unnoticed. The sudden emergence of a specific set of symptoms is not analogous to the disease itself; but, representative of its effects relative to the functional and structural integrity of the social body. It may perhaps be helpful to explore the definition of disease (Polizzi \& Lanier, in press).

Some types of social harm, illness and crime are more illustrative of this than others. For example, Bezuidenhout and Lanier (2010) made an argument showing how the increasing pervasiveness of home invasions in South Africa is negatively impacting the body politic, social norms and individual pathologies. The long-term consequences will only serve to weaken the state, impact tourism, investment and ultimately decrease revenues (not to mention quality of life and health). According to Polizzi, "in its most general sense, social presencing or the social presence of the body refers to the way in which the body becomes viewed, constructed and defined from a variety of social interactions and contexts. At it most mundane, the body of the individual or embodied subject retains what Merleau Ponty has called an intervolvement with world that becomes a fluid and open possibility of social meaning. However, in the absence of such openness, the possibility for embodied subjectivity is denied and the body is reduced to that of a pathological artifact of oppressive processes of control. The criminal body or the criminal shadow is an example of such a process" (2010a: p. 1). The "body" can also refer to the social domain, and as such crime, rape, disease and remedies can be conceptualized (and yes perhaps reified) as being either host entities or symptoms (Polizzi, 2010a, 2010b; Leder, 1990). Reification is a real consideration since molecular biological pathogens are clearly not the same as social forces and processes. Nonetheless the analogy is useful as the South African home invasion example exemplifies, and as rape as a tactical weapon illustrates.

If history is any judge, we can conclude that while the possibilities of exposure to HIV is heightened as a result of conflict, the opportunities of exposure can be significantly reduced with undertaking of proper methods such as those taken in Rwanda. In order to reduce the spread of HIV and combat the act of rape as a weapon of war in Northern Uganda, the UN Security Council and nation sates should adopt stronger and more punitive resolutions dealing with the crisis. Lanier (2010) discusses the issue of marijuana, which is presented by the US government as a "gateway drug" and condemned due to its possibility of creating "health consequences." Lanier (2010) points out; however, that alcohol and tobacco, which are both proven to contribute to massive "disease" are both sold legally without hesitation. Lanier argues that EpiCrim advocates a "health-based Criminal Justice system that would argue that perhaps law should be designed to reduce rather than contribute to social harm, decay and disease" (Lanier, 2010: p. 87). Therefore, EpiCrim would suggest that if the Ugandan governments were to take punitive measures towards those who are utilizing the tactic of "rape as war" it would perhaps reduce overall social harm. On the contrary if the Ugandan government continues to ignore these criminal acts they may be inadvertently contributing to the massive spread of the HIV/AIDS disease. This situation again highlights the importance of the EpiCrim ability to understand the field of Criminology and the field of Health as a unit and lead to more practical solutions to problems that may seem otherwise insurmountable.

The UN Security Council should also attempt to increase the level of punishment for war crimes in hopes of eliminating the impunity problem that exists in Ugandan society. It is unfortunately common for those responsible for acts of sexual violence and rape committed in war to go unpunished for the crimes they commit (VSDVAA, 2005). Lanier (2010) argued, “destructive government policy and inaction can result in an increased incidence of HIV/AIDS in both the United States and South Africa”. The Rwandan case should serve as an example to help tackle the impunity problem in Uganda in relation to the "Rape and War" issue. One of the shortcomings of the Rwandan case was the lack of punitive measures initially taken against the war criminals, therefore, impunity was the biggest reason, that the government; mainly the militia men were able to continue these crimes for such extended periods". Although the International Courts have expended effort towards combating the rape and war problem through prosecution, the national courts in these countries continue to struggle to achieve similar success.

In order to prosecute such cases successfully, local investigations must be prompt, thorough, sensitive, and effective and based on sound theoretical principles such as EpiCrim (LR, 2005). Uganda has recently taken some small steps to set up a war crimes tribunal much like the International Tribunal in Rwanda. Uganda has also appointed judges to preside over a special war crimes tribunal to try leaders of the rebels Lord Resistance Army (LRA); however they have had little success in criminal prosecution (CICC, 2008). Part of the problem is that "many of these countries have failed to create local laws, and/or lack effective court systems to prosecute perpetrators" (LR, 2005). The UN Security Council should most effectively utilize and enforce the Criminal Tribunal created for Uganda in order to hold the war criminals accountable for acts such as rape as a weapon of war. This would allow the new tribunal the ability to prosecute high-ranking military and government officials for extensive human rights violations such as those committed in Rwanda. The UN must also create proper mechanisms for the training of police and military officers of Uganda, so that cases of sexual violence will be handled more efficiently 
(African News, 2008). The UN should also send military troops to Uganda, and require the members to undergo appropriate training and take courses on the effects of HIV.

Next taking preventative measures through education of military members and targeted women, in order to thwart the spread of HIV infection in Northern Uganda is needed. Previous education methods have consisted of Safe Sex education through the medical realm; however, EpiCrim suggest that there are other angles to the problem at hand. First, the mental and emotional state of the criminals and victims should be taken into account when formulating a proper education plan. For example, one of the major reasons that women in Northern Uganda are more likely to be infected with HIV during war times is because, according to the literature, soldiers are more likely to undertake violent actions such as rape in stressful times of war (Lanier, 2010). This aberrant behavior coupled with the fact that many of the LRA returnees are HIV positive with the phrase results in widespread transmission of HIV. Soldiers use force to rape the women in the concentration camps, without the proper use of protection and continue to add to the death count (Olara, 2004). Lanier (2010: p. 78) suggests that if we "construct this group of individuals as dangerous but damaged, our strategies of intervention can become overly focused on the assessment of risk and less on the humanity of the individual." The "humanity" of the individual is precisely what needs to be targeted in the education policy in order for it to be effective enough to prevent future attacks. Preventative education should strive to alter the destructive goals of the military members and help them realize the audacity of their actions and demand a shift in behavior.

This leads to the last policy recommendation to prevent the spread HIV/AIDS and the use of rape; government should attempt to immediately dismantle all concentration camps and improve the quality of health services, and allow those infected women and children already infected a chance to regain their life (Olara, 2004). A VSDVAA (2005) report titled "Rape as a Tool of War: A Fact Sheet" claims that "women and girls constitute more than half of refugees in the world today, and refugee women are particularly vulnerable to crimes of rape and sexual violence" since women are often victims of rape and sexual violence in the hands of border guards, security forces smugglers and locals (VSDVAA, 2005). Women and girls that are unaccompanied are often viewed as sexual property for everyone in refugee camps and may be subjected to forced prostitution as well as "coercion into sex in exchange for food, documents or refugee status" (VSDVAA, 2005). Preventative education should empower the women in the population and provide them with the knowledge they need to fight back.

Much of the funding for the prevention and education of HIV/AIDS can be derived from the already established USAID, and also specifically from the PEPFAR (Presidents Emergency Plan for AIDS) Relief.budget. PEPFAR has been significantly successful in aiding Rwanda, giving them approximately $\$ 39.2$ million in Fiscal Year (FY) 2004, 56.9 million in FY 2005, $\$ 72.1$ million in FY 2006, and approximately \$103 million in FY 2007 to support comprehensive HIV/AIDS prevention, treatment and care programs. PEPFAR provided more than \$123.4 million in FY 2008 (PEPFAR, 2008). The UN Security Council can make important suggestions to the US PEPFAR committee to increase the funds for Uganda, in order to continue the avid prevention of the spreading of HIV/AIDS. The UN Security Council should attempt to collaborate with the
United States in formulating practical ways that money can be used towards the education of the Ugandan population.

\section{Conclusion}

The use of rape as a weapon of war should not be tolerated or allowed to exist. Theoretical explanations such as that advocated by Epidemiological Criminology need to be applied in both preventative and treatment modalities (Barak, 1994, 1998). Rape is not simply a component of war, nor is it incidental (VSDVAA, 2005). The fact that it is widely used in times of conflict shows the "unique power" it holds over women and the power it gives to the rapists (WNN, 2010). Governments must take responsibility to ensure the safety and equality of woman in order to make sure that rape is no longer used as a weapon of aggression (VSDVAA, 2005).

Along with the theoretically based training of government authorities and changing national laws, scholars and others who hold public sway, should also attempt to foster a fundamental change in people's attitudes towards the sexual abuse of women (LR, 2005). The Ugandan government along with the international community has an obligation to protect women and children of Northern Uganda, and similar victims of war in other places. After witnessing the success with the Rwanda case, the UN Security Council should take similar measures to combat the HIV and rape that is currently used as a weapon of war in Uganda before HIV takes an even greater toll on the population. Policy makers, counselors and educators should make use of social sciences theory to perpetuate this necessary change (Barak, 1994, 1998; Robinson, 2004).

Policymakers might also consider a change to their approach in combating the problem of "rape as a weapon of war" and the simultaneous spread of HIV, by adhering to social science precepts such as those suggested by EpiCrim. Attempting to understand, explain and curtail the behavior of war criminals utilizing rape should help policymakers achieve a more successful and effective solution.

\section{REFERENCES}

African News. (2008). Uganda sets up crimes tribunals for rebels. http://www.polity.org.za/article/uganda-sets-up-war-crimes-tribunalfor-rebels-2008-05-28

African Union. (2008). Rwanda: The preventable genocide-International Panel of Eminent Personalities.

http://www.visiontv.ca/old/RememberRwanda/Report.pdf

Aho, J., \& Aho, K. (2009). Body matters: A phenomenology of sickness, disease, and illness. Lanham, MD: Lexington Books.

Akers, T., \& Lanier, M. M. (2009) Epidemiological criminology: Coming full circle. American Journal of Public Health, 99, 397-402. doi:10.2105/AJPH.2008.139808

Barak, G. (1994). Varieties of criminology. Westport, CT: Praegar.

Barak, G. (1998). Integrating criminologies. Boston, MA: Allyn \& Bacon.

Bezuidenhout, C., \& Lanier, M. M. (2010). The impact of violent crime on the RSA psyche, criminal justice system and society: Intervention based on epidemiological criminology. Acta Criminologica, under review.

Chelala, C. (2004). Rape during conflict becoming genocidal in countries with high HIV/AIDS prevalence. URL.

http://speakout.org.za/about/types/type_rape_during_conflict.htm

Chelala, C. (2005). Rape as a weapon of war: It persists in Africa where HIV takes a heavy toll. URL.

http://www.sfgate.com/cgibin/article.cgi?f=/c/a/2005/06/26/

Coalition for the International Criminal Court (CICC). (2008). URL. http://www.iccnow.org/?mod=newsdetail\&news=2684

Durkheim, E. (1897/1951). Suicide: A study in sociology. New York: 


\section{CHOWDHURY ET AL.}

The Free Press.

Deustche Presse-Argentaur (DPA). (2008). Higher AIDS infection rate among Ugandan soldiers.

Elbe, S. (2002). HIV/AIDS and the changing landscape of war in Africa. International Security, 27, 159-177. doi:10.1162/016228802760987851

Friends for Peace in Africa (FPA). (2005). WHO tells Uganda to dismantle camps as deaths rise. URL.

http://www.friendsforpeaceinafrica.org/idps/32-internal-refugees-dis placement/45-who-tells-uganda-to-dismantle-camps-as-deaths-rise.ht $\mathrm{ml}$

Harris, S. (2007). God's hostage. URL.

http://newsweek.washingtonpost.com/onfaith/panelists/sam_harris/2 007/01/women_are_property_1.html

Heidegger, M. (1996). Being and time. New York, NY: SUNY Press.

Human Rights Watch (HRW). (2003). Lasting wounds. URL. http://www.hrw.org/en/reports/2003/04/02/lasting-wounds

Human Rights Watch (HRW). (2004). Women's rights: Fact sheet: Domestic violence and HIV in Uganda. URL.

http://www.preventgbvafrica.org/sites/default/files/resources/dv.hivi nugfactsheet.hrw.pdf

Kramer, A. Akmatov, M., \& Kretzschmar, M. (2010). Principles and aims of epidemiology. In A. Kramer, M. Kretzschmar, \& K. Krickeberg (Eds.), Modern infectious disease epidemiology (pp. 85-99). New York, NY: Springer.

Kovacic, K. (2007-2008). Creating a monster: MS-13 and how United States immigration policy produced "the world's most dangerous gang.” Gonzaga Journal of International Law, 11. URL. http://www.gonzagajil.org/content/view/183/26/

Kuhn, T. (1962). The structure of scientific revolutions. Chicago, IL: The University of Chicago Press.

Lanier, M. M. (2006). The impact of HIV/AIDS on criminology and criminal justice. The International Library of Criminal Justice, Criminology and Penology. Farnham, Hampshire: Ashgate Publishing.

Lanier, M. M. (2009). Epidemiological criminology: A critical crosscultural analysis of the advent of HIV/AIDS. Acta Criminologica, 22, 60-73.

Lanier, M. M. (2010). Epidemiological criminology (EpiCrim): Definition and application. Journal of Theoretical and Philosophical Criminology, 2, 63-103.

Lanier, M. M., \& Henry, S. (2010). Essential criminology (3rd ed.). New York, NY: Westview/Perseus Press.

Lanier, M. M., Lucken, K., \& Akers, T. (2010). Further need for epidemiological criminology. In R. Muraskin (Ed.), Key correctional issues (2nd ed.; pp. 163-174). Englewood Cliffs, NJ: Prentice Hall Publishing.

Leder, D. (1990). The absent body. Chicago, IL: University of Chicago Press.

Lessons from Rwanda (LR). (2005). The United Nations and the prevention of genocide. URL. http://www.un.org/preventgenocide/rwanda/

Lessons from Rwanda (LR). (2005). Sexual violence: A tool of war. http://www.un.org/preventgenocide/rwanda/backgrounder.shtml

Lexis Nexis. (2004). Witnesses say that Nyiramasuhuko ordered militia to "rape all Tutsi women and kill the rest". 3 February 2004.

Lexis Nexis. (1995). Rape increasingly a weapon of war, UNICEF leader says. 15 September 1995

Lexis Nexis. (1998). Rwanda: Historic judgement finds Akayesu guilty of genocide. Africa News, 2 September 1998.

Lutya, T. M., \& Lanier, M. M. (2009). EpiCrim criminological responses to human trafficking of women and girls for sexual exploitation in South Africa. The Stockholm Criminology Symposium, Stockholm, 22-24 June 2009.

Merleau-Ponty, M. (1962). Phenomenology of perception. Southampton: Routledge \& Kegan Paul.

Merton, R. K. (1968). Social theory and social structure. New York, NY: Free Press.

Olara, S. (2004). Rape: The hidden weapon against women in war torn Northern Uganda. URL. http://allafrica.com/stories/200411090860.html

PEPFAR Website. (2008). Country profile: Rwanda. URL. http://www.pepfar.gov/about/opplan08/102013.htm

Poe, R. (2009). To believe or not to believe: The social and neurologycal consequences of belief systems. Bloomington, IN: Xlibris Corporation.

Polizzi, D. (2010a). Phenomenological theory. In C. Bryant (Ed.), Routledge handbook of deviant behavior (pp. 129-134). New York, NY, London, UK: Routledge.

Polizzi, D. (2010b). The social construction of crime and disease: Epidemiological criminology from a phenomenological perspective. The American Society of Criminology Annual Meeting, San Francisco, 17-20 November 2010.

Polizzi, D., \& Lanier, M. M. (2011) Crime as disease: Towards an epidemiological criminology of the social body. Social Theory and Health, under review.

Rakita, S. (2004). Children of Rwanda: Legacy of genocide, the future of Rwanda. URL. http://www.pambazuka.org/en/category/features/21167

Rave Project. (2003). In Uganda. http://www.theraveproject.com/mapdata/uganda.html

Robinson, M. B. (2004). Why crime? An integrated systems theory of antisocial behavior. Upper Saddle River, NJ: Pearson/Prentice Hall.

Schabas, W. A. (1948). Convention on the prevention and punishment of the crime of genocide. URL.

http://www.preventgenocide.org/law/convention/text.htm

Sharlach, L. (2010). Rape as genocide: Bangladesh, the former Yugoslavia, and Rwanda. New Political Science, 22, 89-102. doi:10.1080/713687893

The United Nations. Statute of the tribunal—Annex Article 2. http://www.un.org/ictr/statute.html

The United Nations. (1994). UN resolution 955. http://www.un.org/ictr/english/Resolutions/955e.htm

Virginia Sexual and Domestic Violence Action Alliance (VSDVAA). (2005). Rape as a tool of war: A fact sheet (amnesty international). URL. http://www.vadv.org/Resources/airapeinwar.html

Wallis, D. (2008). Peace women: HIV rates soar in ear-torn Northern Uganda. URL. http://www.peacewomen.org/news/Uganda/Sept04/

Webster's. (2009). Disease. (n.d.). Dictionary.com Unabridged (v 1.1). URL. http://dictionary.reference.com/browse/disease

Womens News Network. (2010). New report outlines untold stories of women and war. URL. http://womennewsnetwork.net/2010/10/20/gender-data-unfpa/

World Health Organization. (2004). The sanitation challenge: Turning Commitment into reality. URL.

http://www.who.int/water_sanitation_health/hygiene/sanchallengeco mp.pdf

Zaitzow, B. (2001). Whose problem is it anyway? Women prisoners and AIDS/HIV. International Journal of Offender Therapy and Comparative Criminology, 45, 673-690. doi:10.1177/0306624X01456004 